\title{
Schumacher reconsidered
}

\section{Eric Ashby}

Small is Possible. By George McRobie. Pp.331. ISBN hbk 0-224-01858-2; ISBN pbk 0-06-090694-4. (Jonathan Cape/ Harper \& Row: 1981.) Hbk £7.95; pbk $\$ 5.95$.

THERE is a mysterious jackpot logic about best-selling books on the environment. Why has Vogt's Road to Survival sunk without trace while Leopold's Sand County Almanac is quoted and requoted? Both were published a generation ago; both are elegantly written. Why is Thoreau, who liked his wilderness to be as tame as a tabby cat, still regarded as a conservationist's guru? And why is Schumacher's Small is Beautiful treated as a seminal tract in self-sufficiency? Surely Tolstoy had similar ideas and there were Tolstoyan communities (well described by W.H.G. Armytage in Heavens Below, published 20 years ago) in Britain in the 1890s.

Small is Beautiful, I'm told, still sells well, thanks (ironically) to the large-scale techniques of book production and marketing. It is seductively written and full of wisdom. But wisdom, alas! is only a minor ingredient in practical politics. As devotional reading, Schumacher's book is still popular; but as a blueprint for a new economic policy in the manifesto of a political party (except, perhaps, the misnamed ecology party) it's not a starter. Not only in the capitalist world but in the communist world too, small may well be beautiful, but it is the giant enterprise that provides energy, packaged foods in the supermarket, communications, transport, the dish-washer in the kitchen and the car in the garage. The communes in China are an exception to this generalization, but will they survive as China becomes a great industrial power? For Britain, at any rate, it does not seem unduly cynical to assume that if a choice had to be made at the polls between an economic life style which was, in Schumacher's sense, beautiful, and one which gave the greatest material comfort to the greatest number of people, then beauty would lose out.

So the stock comment on Small is Beautiful is "beautiful, no doubt; practicable, no". Therefore when a sequel appears with the title Small is Possible, it should be accepted as a challenge to reexamine Schumacher's thesis. It is in that spirit that I read the book.

George McRobie, the author, was Schumacher's assistant and co-founder of the Intermediate Technology Development Group, ITDG (one of the many - far too many - acronyms in the book). He does not pretend to write with the felicity of Schumacher but he doggedly assembles evidence to validate the book's title. The book is, for the most part, an annotated catalogue of enterprises in intermediate or "appropriate" technology which are consistent with Schumacher's thesis, namely that conventional capital-intensive projects are a disaster in Third World countries and may well be the signpost toward disaster in industrialized countries; and - this is the message of the book that there are alternative small peopleintensive projects which are viable. McRobie gives a list, with addresses, of nearly 100 organizations concerned with appropriate technology engaged in hundreds of little experiments. The evidence persuades me (at any rate) that there is a minority movement to reject the life-style of what used to be called the militaryindustrial-complex; not on political grounds but on what may become a much firmer foundation: moral grounds. It is no more than a sprinkling of enthusiasts (some of them cranks) in the interstices between super-highways, power stations, acres of petrochemical works and refineries; uncoordinated, fragmented. But something interesting is going on, and if the fragments coalesce a new life style might emerge.

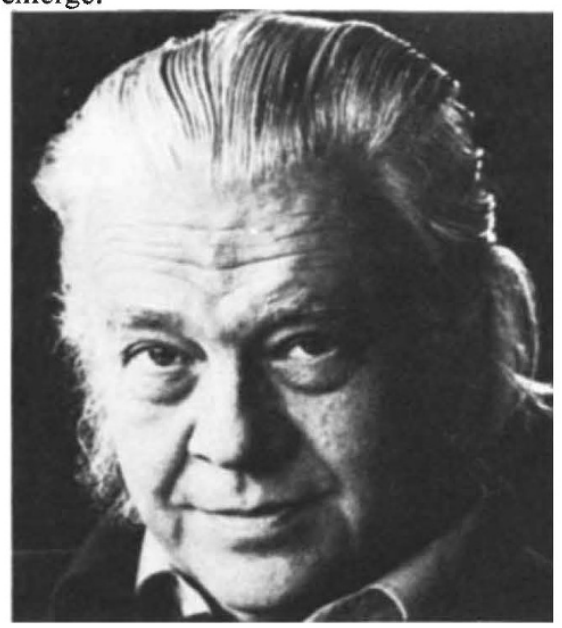

The late E.F. Schumacher, prophet of self-sufficiency.

What is going on? Here are a few samples taken from McRobie's book.

He deals first with the most urgent and relevant application of Schumacher's thesis: the design of equipment for agriculture and industry in Third World countries. The principle is simple. In countries with surplus manpower, and without technical sophistication, capital investment per worker has to be as low as possible. When a British trade mission went to Nigeria, Schumacher's group (ITDG) put into their hands a stencilled Guide to Small-scale Equipment for Rural Development, "of animal and manoperated agricultural equipment obtainable from little hole-and-corner firms in Britain". Not at all what the mission intended to propagate in Nigeria; but (said Schumacher) "This thing was torn out of their hands by people who said: For the first time you bring us something of interest, instead of the usual glossy catalogues". That was 15 years ago. Since then the ITDG has had an impressive record of service to Third World countries. A building panel set up, in five African countries, units for making bricks at a capital cost of $£ 400$ per workplace, compared with $£ 40,000$ per workplace in a large modern brickworks; and it invented and put into production a fibre-reinforced cement for roofing at a fraction of the cost of the normal commercial product. A water group published handbooks on the making of pumps, wells and low-cost irrigation systems. A farming group has designed and put into production (in Zambia and Nigeria) workshops for making machines for weed-control, groundnut harvesting and fibre stripping. A transport unit based on the Engineering Department at Oxford has designed the Oxtrike: a cycle rickshaw which can be made in Third World countries. Windmills in Ethiopia, water pumps in Nepal, minihydro generators - all locally made replace the imported equipment which cannot be kept in good repair without skilled technicians. And - most imaginative of all - the Rural Health Panel has, under the skilled guidance of $\mathrm{Dr}$ Katherine Elliott, promoted the training of auxiliaries in health care, in collaboration with the World Health Organization.

These efforts may seem to be trivial crumbs to offer the Third World when set beside the massive expenditures on steel mills for India or on the Volta Dam for Ghana; too trivial for all the effort involved. But they have an importance which cannot be quantified: they may, with luck, convince the Third World that it does not want to ape Europe and America in its patterns of society. And it may help to repair some of the damage we have done in exporting the wrong kinds of goods and education to the Third World. Thus, when we exported medical education to the university colleges of tropical Africa we arranged (with the noblest of motives) that its quality and content would be indistinguishable from that in a London medical school. The surgical staff, training doctors skilled to remove the gallstones of cabinet ministers in the capital city, regarded with impatience the activities of an African professor of social medicine, who put his efforts into the holding of competitions in the villages for the construction of earth closets. Anyone who dared to suggest that the prime need was for medical auxilliaries (as the Soviet Union and China had) was scarified with criticism. The universities were suspicious of any subject in the curriculum which would not have been appropriate in London. One encouraging message in McRobie's book is that this technological snobbery is diminishing. African universities are becoming relevant to African problems. Countries where Small has been 
Practicable (if not Beautiful) for millennia may still have a chance to escape some of the social perils of modern technology.

What about the industrial West, where the proudest boast of technologists is that they save manpower at the cost of capital investment per workplace? It would be stupid to dismiss the enormous social benefits of mass production. For every one man whose life is dissipated on a production line in British Leyland there must be hundreds of families whose lives have been liberated by the possession of a car. Holidays, picnics, visits to friends and relations, life in a suburb and a short drive to the office: all these are incomparably easier to secure than they were for the socalled lower classes when I was a boy. While there was full employment, and material progress brought with it some improvement in the quality of life, the achievements of the industrial West were welcomed. For the first generation owner of a car and a refrigerator and an air ticket to Majorca, the warnings of Schumacher were dismissed as neurotic.

It is a different story today. Thanks to education and the media, the unemployed are more articulate than they were in the 1930 s. They do not equate unemployment with leisure, even though they are paid to be unemployed. To be without work is as dangerous as to be without love. So, suddenly, the application of Schumacher's ideas (and not just Schumacher's: they are the ideas of William Morris and Tolstoy in modern dress) becomes relevant and politically important. McRobie describes how hundreds of small groups of people in America, Canada and (on a smaller scale) in Britain have detached themselves from the conventional pattern of society, to seek a pattern which does not have the formula "economies of scale" woven into the design. In America some of the experiments have official support. There is a National Center for Appropriate Technology, inspired by Senator Mike Mansfield. There is the California Office of Appropriate Technology, started by order from Governor Jerry Brown, with a budget of $\$ 900,000$, encouraging the use of solar energy, and designing small-scale sewage systems and techniques for aquaculture. In the Bronx, some of which is a waste of derelict city lots, an Institute for Local Self Reliance has mobilized local labour to cultivate gardens and rehabilitate decayed property. And in Canada - in many ways the most enlightened of Western nations - there is in the ugly mining town of Sudbury a project called "Sudbury 2001" which, with a provincial government grant of $\$ 600,000$, is preparing some of the workforce for the inevitable redundances they see ahead.

McRobie's chapter on the "alternatives" movement in Britain is less encouraging. It seems (perhaps there is another side to the story) that neither governments nor trade unions have taken much interest in the possibilities of small collectives. The experiences of the Kirkby Manufacturing and Engineering Ltd (KME) and the Scottish Daily News do not generate much confidence. Of course it is sheer fantasy to imagine that ICI, BP and the Central Electricity Generating Board will dissolve in a flood of little collectives making their own paints, heating their farms with home-made methane, using windmills knocked together by the local blacksmith. But the unemployed displaced

by a combination of world diseconomy and new technology are going to demand work. If they do not get work, society as we know it may be shattered. If we have to invent work not to produce things for profit but to satisfy a deep genetically coded human need, then perhaps Schumacher's ideas are worth another thought.

Lord Ashby is Chancellor of Queen's University, Belfast, and a Fellow of Clare College, Cambridge.

\section{Science fiction as Marxism}

\section{James Gorman}

Robert A. Heinlein: America as Science Fiction. By H. Bruce Franklin. Pp. 232. ISBN hbk 0-1950-2746-9; ISBN pbk 0-19502747-7. (Oxford University Press: 1981.) Hbk \$18.95, £10; pbk \$4.95, £3.95.

ReAding H. Bruce Franklin on Robert Heinlein is a bit like reading an analysis of a sexual farce by a stiff-necked, bible-bound fundamentalist who can never get his mind off the fact that sex is, after all, sinful. Franklin has produced a painstakingly detailed Marxist analysis of what, at its best, is flashy escapist fiction. Heinlein's heroes, his cynicism and sentimentalism, his taste for adventure, all his tales of space exploration, war, sexual fantasy, time travel and immortality become a rather dreary reflection of the contradictions of capitalism in the United States.

Franklin leaves the science in the fiction more or less alone; this omission does no disservice to Heinlein. Science only provides him with the authority by which reality is breached - it is the excuse for the reader to believe in the fantasy. When it suits his purpose, Heinlein is not averse to using magic in its place.

Heinlein is at least as fond of social theory as he is of science, and his books are full of expostulation on one half-baked political philosophy or another. And, as Franklin points out, he does reflect his times. In the 1950s he produced anticommunist novels; in the 1970s he explored narcisstic sexual excess in some of the worst writing of his career. And, in 1961, at the beginning of one of America's most notorious decades, he produced what is probably his most popular book, Stranger in a Strange Land. In it a young human being, raised on Mars, by Martians, comes to Earth, views us all through alien, though human eyes, and finally founds a religion that is part universal sexual love, part hucksterism, part anarchism and part violent elitism. The gentle, loving hero is in the habit of making his enemies, and other undesirables, disappear by a wink of the mind, a trick he learned on Mars.

This is, indeed, very close to "America as Science Fiction". But when Franklin presses his point to argue that the hero "embodies our most infantile fantasies and the central goal of bourgeois ideology the unfettered freedom of the individual will', he is less convincing. Indeed, when, throughout the book, he holds up Heinlein as a mirror that reflects the nature of capitalist society, he undermines his case by two unfortunate omissions - he leaves out Heinlein, and he makes his analysis on the basis of unargued and undemonstrated assumptions.

Where indeed is Heinlein in all of this? Franklin gives us only a thumbnail biography, which concentrates more on the economic conditions in the country when the author grew up than it does on Heinlein himself. And where is Heinlein's imagination, his writing skill, his ability to create compelling stories? A writer of fiction is less a mirror than a lens, that refracts rather than reflects the light of his culture, bending it with his own idiosyncrasies. In Franklin's formula the curve of Heinlein's lens is missing.

Also missing is some back-up for his ready-made Marxism. It may well be true, as he notes in passing, that the conditions of the two main groups of workers in America before World War II were "the debt peonage characteristic of the majority of Black rural workers and the wage slavery of mine and factory labor", and that "class struggle . . . has constituted actual human history", but his case would be stronger if he demonstrated his points rather than asserting them. Nor are these isolated examples. He tells us, for instance, that "If the will is free to do anything it wishes, the will is free from the apparent laws of the physical universe and also free from the apparent laws of human social development"'. He doesn't tell us what either set of laws are, perhaps assuming that the precepts of dialectical materialism are as well known and widely accepted as gravity.

What Franklin's book could use, finally, is a bit more of an internal dialectic. If we were to see the clash of culture and individual in Heinlein's work, we might come away with a richer understanding of the author, and of America.

James Gorman is a staff writer on Discover magazine. 